\title{
SKENARIO PENGELOLAAN KUALITAS AIR SUNGAI METRO KOTA MALANG DARI ANALISA DAYA TAMPUNG BEBAN PENCEMARAN
}

\section{MANAGEMENT SCENARIO OF METRO RIVER'S WATER QUALITY FROM WASTE ASSIMILATIVE CAPACITY}

\author{
Evy Hendriarianti ${ }^{(1)}$, Herry Setyobudiarso ${ }^{(2)}$, Rusdiawan Endra Triono ${ }^{(3)}$ \\ Jurusan Teknik Lingkungan, ITN, Malang \\ Email: hendriarianti@yahoo.com ${ }^{(1)}$
}

\begin{abstract}
Abstrak
Peningkatan beban pencemaran di sepanjang aliran sungai Metro menyebabkan penurunan daya tampung beban pencemaran sungai. Penurunan daya tampung mempengaruhi fungsi sungai sebagai sumber air dan habitat biota. Tujuan dari penelitian ini adalah untuk mengetahui daya tampung beban pencemaran yang dimiliki Sungai Metro pada skenario pengelolaan yang ditentukan. Metode yang digunakan adalah melakukan simulasi parameter kualitas COD dalam berbagai skenario dengan menggunakan aplikasi Qual 2K. Selanjutnya dilakukan perhitungan daya tampung beban pencemaran. Hasil uji validasi model menunjukan $\mathrm{x}^{2}$ hitung $<\mathrm{x}^{2}$ Tabel sehingga model dapat digunakan untuk simulasi, yaitu 1,09 untuk $\mathrm{x}^{2}$ hitung dengan nilai $\mathrm{x}^{2}$ Tabel adalah sebesar 1,145 . Dari hasil penelitian diketahui bahwa daya tampung beban pencemaran paling besar Sungai Metro pada skenario 2, yaitu 321,408 kg/hari - 1.797,768 kg/ hari. Pada skenario 2, kondisi hulu sesuai dengan baku mutu sungai kelas II dan kuantitas beban pencemaran pada kondisi eksisting, kualitasnya sesuai dengan baku mutu air limbah. Segmen 1 sungai Metro memiliki beban pencemaran yang paling tinggi sehingga untuk mencapai kondisi terbaik seperti pada skenario 2 harus dilakukan penurunan beban pencemaran COD sebesar 30,09\%.
\end{abstract}

Kata kunci : aplikasi Qual 2K, beban pencemaran COD, daya tampung sungai, simulasi konsentrasi pencemar.

\begin{abstract}
Metro rivers pass through Malang city and ends at Karangkates Dam. Pollution load increase as long as river flow cause water assimilating capacity reducing. This will influence directly to the river function as water resource and biota's habitats. This research aims to know how much water assimilating capacity that are belong to Metro river for existing condition and to predict them for certain condition scenarios. The method used Q2K application to make water quality model of Metro river. Then the verified model was used to simulate the various scenario of certain condition. Next, simulation output was used to calculate the waste assimilating capacity that is a margin between pollution load and required standar of pollution load. The validation test result show that the model can be used to water qualiy simulation because the value of calculated chi kuadrat smaller (1.09) than chi kuadrat table value (1.145). From water quality simulation result and water assimilating capacity calculation, scenario 2 is the best condition for today where the upstream's water quality of Metro river is appropriate with water quality standard required and the point sources's wastewater quality are appropriate with wastewater quality standard required. The first segment of Metro river model have highest pollution loads. So, to get the best condition of water quality with second scenario, the pollution load of COD must be reduced as 30,09\%.
\end{abstract}

Keywords: pollution load of COD, Qual $2 \mathrm{~K}$ application, waste assimilating capacity, simulation of pollutant concentration,. 


\section{PENDAHULUAN}

Sungai Metro merupakan basin block daerah aliran sungai Brantas sub (Daerah Aliran Sungai DAS) Brantas hulu. Sungai Metro menjadi sumber air bagi kegiatan manusia sebagai air bersih, air irigasi, air industri, air penggelontoran dan air tambak bagi daerah hilir aliran sungai Brantas dari potensi sebesar 103 juta $\mathrm{m}^{3} /$ detik (Brantas, 2006).

Potensi penyediaan air sungai Metro ini terancam dengan adanya kegiatan pembangunan yang tidak memperhatikan aspek konservasi sumber air. Hal ini ditunjukkan dengan semakin menurunnya luasan hutan dan lahan resapan air lainnya. Analisa tata guna lahan dengan menggunakan citra satelit aster tahun 2005 dan pembandingnya dengan data dari Bakosurtanal tahun 1999, menunjukkan penurunan luas lahan hutan di Wilayah Sungai (WS) Brantas sebesar 6,69\% selama tahun 1999-2005. Sementara luas lahan pemukiman naik $1 \%$. Pola penggunaan lahan yang tidak konservatif ini juga berpotensi menurunkan potensi air, meningkatkan resiko erosi, sedimentasi dan banjir. Berdasarkan hasil perhitungan dengan menggunakan metode USLE diketahui bahwa besarnya kehilangan tanah per satuan luas lahan per tahun di sub DAS Kali Brantas Hulu adalah sebesar 98,99 ton/ha/tahun atau sekitar $1.117 .320 \mathrm{~m}^{3} /$ tahun (Brantas, 2006).

Seperti telah dijelaskan diatas, dari sisi kuantitas air sungai mengalami potensi penurunan. Sedangkan dari sisi kualitas kondisinya juga tidak berbeda. Sumber polutan sungai dari aktifitas pembuangan limbah domestik, industri dan pertanian. Sedikitnya 10 titik yang terbentang disepanjang DAS Brantas di wilayah Malang Raya (Kota/Kabupaten Malang dan Kota Batu) tercemar limbah. Limbah yang mencemari tersebut sebagian besar berasal dari limbah rumah tangga, pertanian, serta kegiatan industri. Saat ini kualitas air sungai di Kota Malang, khususnya di Sungai Brantas masih belum menunjukkan adanya penurunan. Dalam pemeriksaan terakhir, air Sungai Brantas masih tetap berada dalam kategori air sungai kelas C-D (http://kali-brantas-kota malang.weebly.com/ berita.html, 2012)

Sungai secara alami mempunyai keterbatasan dalam kemampuannya melakukan self purification. Hal ini diperparah dengan semakin kompleksnya kandungan limbah dewasa ini yang akan semakin membuat proses self purification menjadi sangat sulit dilakukan oleh sungai. Ditambah dengan perilaku masyarakat di sekitar aliran sungai yang membuang limbahnya langsung ke sungai sehingga membuat beban pencemaran sungai menjadi semakin bertambah. Daya tampung beban pencemaran air adalah kemampuan air pada suatu sumber air untuk menerima masukan pencemaran tanpa menyebabkan air tersebut tercemar. Sedangkan beban pencemaran adalah jumlah suatu unsur pencemar yang terkandung dalam air maupun limbah. Apabila besaran beban pencemaran pada sungai melebihi daya tampung beban pencemaran sungai itu sendiri maka yang terjadi adalah sungai tersebut menjadi tercemar (Nugraha dan Dwi, 2008).

Sungai Metro yang mengalir di tengah Kota Malang, dimana Kota Malang sendiri memiliki permukiman penduduk di kawasan aliran sungai yang sangat padat tentu akan sangat mempengaruhi kualitas air sungai Metro iu sendiri. DAS Metro merupakan Daerah Pengaliran Sungai (DAS) Metro yang mengalir dari saluran arah Utara ke Selatan melalui bagian Barat Kota Malang.

Melihat dari permasalahan pencemaran sungai Metro, perlu dilakukan upaya pengelolaan yang dirumuskan dari perhitungan daya tampung beban pencemaran sungai. Perhitungan daya tampung beban pencemaran sungai menggunakan metode neraca massa ataupun metode Streeter-Phelps (KMNLH, 2003). Dalam penelitian ini perhitungan neraca massa dilakukan dengan menggunakan software Qual2k untuk memodelkan kualitas air sungai tersebut (Chapra, 2003). Hasil dari sebuah pemodelan yang utama 
adalah prediksi keadaan pada kondisi dan waktu yang berbeda (Baidowi, 2010). Sehingga dengan scenario pengelolaan dapat diprediksi kondisi daya tampung beban pencemaran sungai. Pengelola sumber daya air sebaiknya menggunakan metode analitis untuk membantu merumuskan strategi pengelolaan air yang berkelanjutan. Untuk mendapatkan pengelolaan kualitas yang terpadu dari hulu ke hilir dibutuhkan pemodelan matematis kualitas air. Pemodelan kualitas air memerlukan pengumpulan data seperti hidrogeometri sungai, kualitas air sungai dan titik pembuangan limbah sepanjang sungai (Hendriarianti, 2012). Penelitian ini bertujuan untuk merumuskan upaya pengelolaan kualitas air menggunakan metode perhitungan daya tampung beban pencemaran yang dimiliki Sungai Metro melalui simulasi parameter kualitas COD dalam berbagai skenario dengan menggunakan aplikasi Qual 2K.

\section{METODA}

\section{Segmentasi Sungai}

Segmentasi sungai mempunyai fungsi untuk membagi sungai menjadi ruas-ruas yang lebih kecil sehingga memudahkan dalam hal penelitian. Pada penelitian penentuan daya tampung beban pencemaran ini, Sungai Metro dibagi menjadi lima segmen sungai. Dasar penetapan segmen ini adalah berdasar dengan alokasi persebaran dari daerah permukiman penduduk di sepanjang aliran Sungai Metro.

\section{Pengukuran Debit Air Sungai}

Pada penelitian ini, pengukuran debit air sungai dilakukan pada masing-masing segmen untuk mengetahui jumlah debit pada masing-masing segmen. Pengukuran debit sungai pada penelitian ini akan dilakukan dengan menggunakan alat ukur kecepatan sungai current meter. Prinsip kerja dari current meter yaitu propeler berputar dikarenakan partikel air yang melewatinya.
Jumlah putaran propeler per waktu pengukuran dapat memberikan kecepatan arus yang sedang diukur.

\section{Pengambilan Sampel}

Metode pengambilan sampel dalam penelitian ini menggunakan teknik grab sample. Hal ini dilakukan karena frekuensi pengambilan sampel yang hanya satu kali dan untuk lebih mengkondisikan sampel seperti kondisi di badan air itu sendiri. Sampel akan diambil pada pukul 68 pagi. Hal ini dikarenakan pada interval waktu tersebut, diperkirakan debit point source yang berupa limbah domestik akan mencapai titik puncaknya yang disebabkan meningkatnya aktifitas rumah tangga. Pengambilan sampel sendiri pada penelitian ini terdiri dari dua jenis, yaitu pengambilan sampel air sungai dan pengambilan sampel air limbah.

\section{Pengumpulan Data Sekunder}

Data sekunder yang dibutuhkan meliputi peta sungai, data kualitas air sungai selama lima tahun terakhir, dan data hidrogeometri sungai. Data hidrogeometri sungai ini meliputi data dimensi sungai, slope, dan side slope sungai. Data sekunder ini diperoleh dari instansi-instansi terkait seperti Perum Jasa Tirta I dan Badan Lingkungan Hidup Kota Malang.

\section{Pemodelan Dengan Qual 2K}

Data-data primer maupun sekunder yang tela didapatkan kemudian dimasukan ke dalam sel-sel Qual 2K. Data-data tersebut antara lain data tentang debit sungai dan air limbah, konsentrasi BOD dan COD untuk sungai dan air limbah, segmentasi sungai, panjang tiap segmen sungai, dan letak masing-masing segmen dan point source.

\section{Kalibrasi Model}

Kalibrasi model dilakukan untuk mencari nilai koefisien BOD Hydrolysis Rate, BOD 
Tabel 1.

Skenario Simulasi Penentuan Daya Tampung Beban Pencemar Sungai

\begin{tabular}{|c|c|c|c|}
\hline Skenario & $\begin{array}{c}\text { Kualitas } \\
\text { Headwater }\end{array}$ & Data Sungai & $\begin{array}{c}\text { Sumber } \\
\text { Pencemar }\end{array}$ \\
\hline Eksisting & Eksisting & Eksisting & Eksisting \\
\hline 1 & Eksisting & Eksisting & $\begin{array}{c}\text { Memenuhi } \\
\text { Baku Mutu Air } \\
\text { Limbah }\end{array}$ \\
\hline 2 & $\begin{array}{l}\text { Memenuhi Baku } \\
\text { Mutu Air Kelas } \\
\text { II }\end{array}$ & Eksisting & $\begin{array}{c}\text { Memenuhi } \\
\text { Baku Mutu Air } \\
\text { Limbah }\end{array}$ \\
\hline 3 & $\begin{array}{l}\text { Memenuhi Baku } \\
\text { Mutu Air Kelas } \\
\text { II }\end{array}$ & $\begin{array}{c}\text { Hasil } \\
\text { Skenario } 2\end{array}$ & $\begin{array}{c}\text { Estimasi Tahun } \\
2018\end{array}$ \\
\hline 4 & Eksisting & Eksisting & $\begin{array}{c}\text { Estimasi Tahun } \\
2018\end{array}$ \\
\hline
\end{tabular}

Oxydation Rate, dan COD Decay. Metode yang digunakan adalah dengan trial and error hingga model mendekati keadaan yang ada di lapangan.

\section{Perhitungan Daya Tampung Beban Pencemaran Sungai}

\section{Verifikasi Model}

Model yang telah sesuai dengan kondisi sebenarnya kemudian dilakukan validasi dengan metode uji khi kuadrat. metode uji khi kuadrat atau $\mathrm{X}^{2}$ dimana apabila beda pengukuran di lapangan dengan hasil model memenuhi kriteria uji, maka model dapat digunakan. Hasil perhitungan $X^{2}$ ini kemudian dibandingkan dengan nilai $X^{2}$ dalam Tabel pada $\alpha=0,95$. Jika $\mathrm{x}^{2}$ hitung $>\mathrm{x}^{2}$ Tabel, maka model ditolak, sedangkan jika $\mathrm{x}^{2}$ hitung $<\mathrm{x}^{2}$ Tabel, maka model diterima (Sudjana, 2001).

Setelah diperoleh hasil beban pencemaran yang diijinkan dan beban pencemar terukur, kemudian baru dapat dilakukan perhitungan daya tampung beban pencemar sungai dengan rumus sebagai berikut :

\begin{tabular}{|c|c|c|c|}
\hline Daya & & Beban & Beban \\
\hline Tampung & & Pencemaran & Pencemar \\
\hline Beban & $=$ & yang & an \\
\hline $\begin{array}{l}\text { Pencemaran } \\
(\mathrm{kg} / \mathrm{hr})\end{array}$ & & $\begin{array}{l}\text { Diijinkan } \\
(\mathrm{kg} / \mathrm{hr})\end{array}$ & $\begin{array}{l}\text { Terukur } \\
(\mathrm{kg} / \mathrm{hr})\end{array}$ \\
\hline
\end{tabular}

\section{Skenario Simulasi}

Simulasi ini dilakukan bertujuan untuk mewakili kondisi eksisting dan mengestimasi keadaan pada masa mendatang. Dalam teknik simulasi dengan Qual 2k ini menggunakan 5 (lima) skenario, seperti pada Tabel 1 . Konsentrasi pencemar yang dihasilkan pada tiap skenario kemudian dilakukan perhitungan untuk mendapatkan beban pencemaran yang diijinkan baku mutu air kelas II menurut Peraturan Pemerintah No 82 tahun 2001 tentang Kualitas dan Pengendalian Pencemaran Air dengan rumus perhitungan sebagai berikut :

Beban Pencemar yang Diijinkan $(\mathrm{kg} / \mathrm{hr})$

$$
=\mathrm{Q} \times \mathrm{Cx} 86,4
$$

Keterangan : $\mathrm{Q}=$ Debit Limbah $\left(\mathrm{m}^{3} / \mathrm{dt}\right)$

$$
\mathrm{C}=\text { Konsentrasi Baku Mutu }
$$
Pencemar (mg/l) 


\section{HASIL DAN PEMBAHASAN}

\section{Pembagian Segmen Sungai Metro}

Dasar penetapan segmen ini adalah berdasar dengan alokasi persebaran dari daerah permukiman penduduk di sepanjang aliran Sungai Metro. Peta pembagian segmen sungai (reach system) dalam model kualitas air sungai Metro dapat dilihat pada Gambar 1.

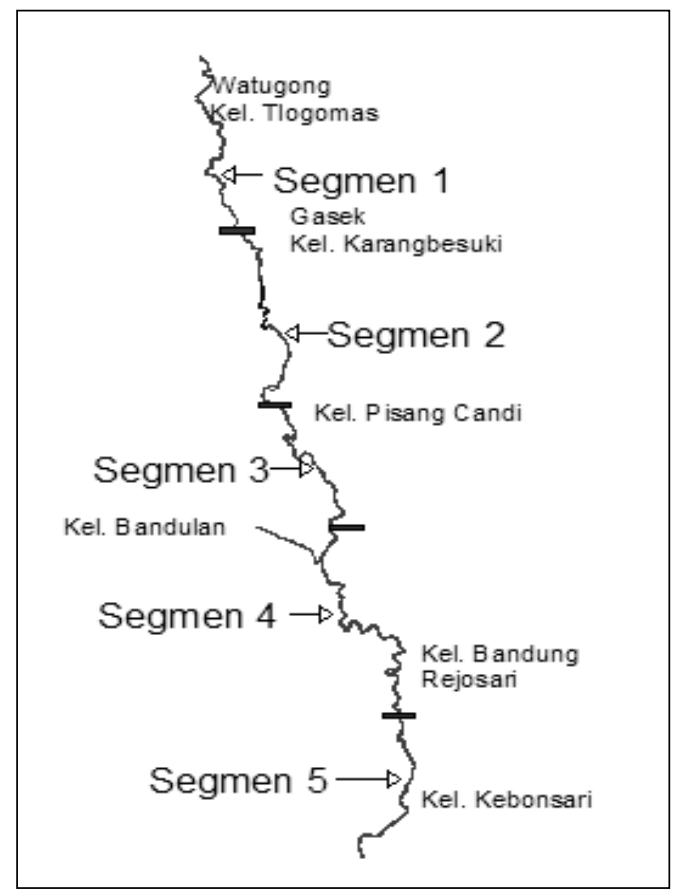

Gambar 1. Segmentasi Sungai

\section{Debit dan Kualitas Air Sungai}

Debit Sungai Metro yang telah diukur di lapangan untuk lima segmen sungai cenderung meningkat. Hal ini disebabkan semakin menuju hilir, luas penampang sungai cenderung lebih besar sehingga berpengaruh terhadap debit yang dihasilkan.

Parameter kualitas air Sungai Metro yang ditinjau adalah COD. Parameter ini diambil karena biasanya digunakan sebagai indikasi utama terjadinya pencemaran sebuah badan air. Kondisi kualitas air sungai Metro dapat dilihat pada Tabel 2.

\section{Debit dan Kualitas Air Limbah}

Sumber pencemar yang dianalisa adalah sumber pencemar yang langsung masuk ke dalam badan air Sungai Metro. Sumber pencemar yang masuk ke dalam badan air merupakan sumber pencemar dari limbah domestik, hal ini dikarenakan daerah sempadan sungai merupakan daerah permukiman warga.

Tabel 2. Debit dan Kualitas Air Sungai Metro

\begin{tabular}{ccc}
\hline Segmen & $\begin{array}{c}\text { COD } \\
(\mathbf{m g} / \mathbf{l})\end{array}$ & $\begin{array}{c}\text { Debit } \\
\left(\mathbf{m}^{\mathbf{3}} / \mathbf{s}\right)\end{array}$ \\
\hline Segmen 1 & 25,6 & 0.75 \\
Segmen 2 & 23,5 & 1.60 \\
Segmen 3 & 20,8 & 0.94 \\
Segmen 4 & 19,2 & 2.66 \\
Segmen 5 & 11,5 & 4.46 \\
\hline
\end{tabular}

Pengambilan sampel air limbah dilakukan pada interval waktu pukul 6.00-8.00. Hal ini dilakukan dengan asumsi bahwa estimasi kegiatan domestik mengalami puncaknya pada interval waktu tersebut. Hasil pengukuran debit dan kualitas air limbah domestik disajikan pada Tabel 3 .

Tabel 3. Debit dan Kualitas Air Limbah

\begin{tabular}{crc}
\hline Lokasi & $\begin{array}{c}\text { Konsentrasi } \\
\text { COD }(\boldsymbol{m g} / \mathbf{l})\end{array}$ & $\begin{array}{c}\text { Debit } \\
\left(\mathbf{m}^{3} / \mathbf{s}\right)\end{array}$ \\
\hline Merjosari & 267,20 & 0,0064 \\
Karang & 129,60 & 0,0675 \\
$\begin{array}{c}\text { Besuki } \\
\text { Pisang } \\
\text { Candi }\end{array}$ & 20,80 & 1,0200 \\
Bandulan & 161,60 & 0,0086 \\
Sitirejo & 107,80 & 0,0052 \\
\hline
\end{tabular}

\section{Pemodelan Dengan Qual 2K}

Model yang dibuat adalah model kualitas untuk parameter COD. Model kualitas yang sudah terverikasi akan digunakan untuk melakukan simulasi berdasarkan skenario -skenario yang 
telah ditentukan. Selanjutnya output hasil simulasi model digunakan untuk menghitung nilai daya tampung beban pencemar sungai. Metro menunjukkan kinerja model yang masih Hasil running awal parameter kualitas air sungai jauh dari kondisi di lapangan.

Tabel 4. Koefisien Hasil Kalibrasi

\begin{tabular}{ccccc}
\hline Reach & \multicolumn{2}{c}{ CBOD } & \multicolumn{2}{c}{ Generic Constituent (COD) } \\
\hline Label & $\begin{array}{c}\text { Hydrolysis } \\
\text { Rate }(/ \mathbf{d})\end{array}$ & $\begin{array}{c}\text { Oxidatio } \\
\mathbf{n} \\
\text { Rate }(/ \mathbf{d})\end{array}$ & $\begin{array}{c}\text { Decay } \\
\text { Rate }(\mathbf{d})\end{array}$ & $\begin{array}{c}\text { Settling } \\
\text { Velocity } \\
(\mathbf{m} / \mathbf{d})\end{array}$ \\
\hline Tlogomas & 7 & 0,5 & 16,5 & 0,5 \\
Karang Besuki & 7 & 0,5 & 15,2 & 0,5 \\
Pisang Candi & 2,5 & 0,25 & 4,5 & 0,5 \\
Bandulan & 1,5 & 0,25 & 4,5 & 0,5 \\
Bandung Rejosari & 8,5 & 0,5 & 16,5 & 0,5 \\
\hline
\end{tabular}

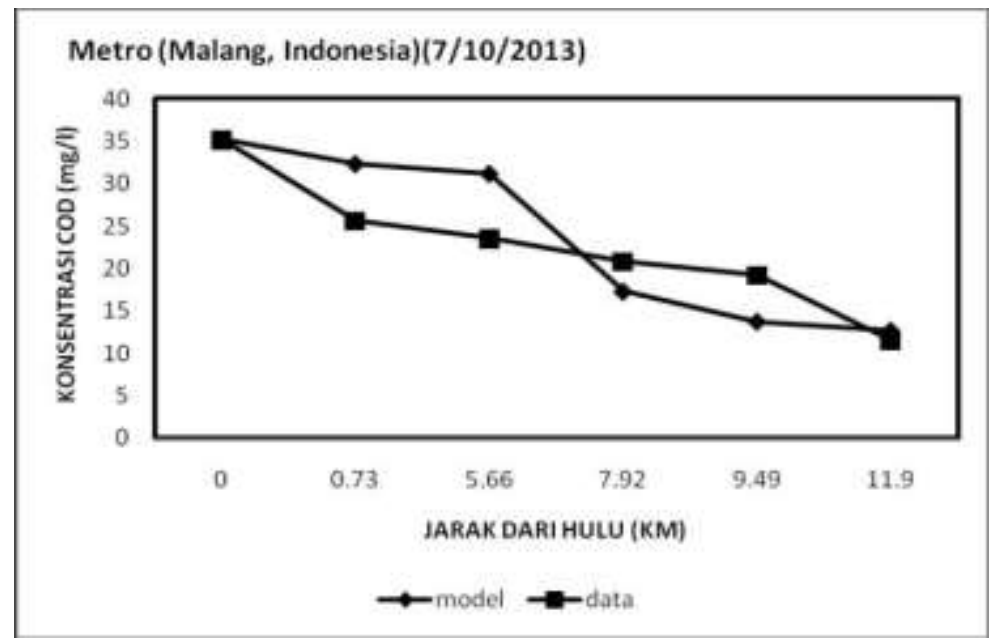

Gambar 2. Hasil Kalibrasi COD

Dari nilai Chi Kuadrat menunjukkan nilai nilai $\mathrm{X}^{2}$ hitung lebih besar (6.30) dari nilai nilai $\mathrm{X}^{2}$ Tabel (1.145). Sehingga selanjutnya dilakukan kalibrasi model sampai diperoleh nilai model yang mendekati data.

\section{Kalibrasi Model}

Kalibrasi dilakukan dengan melakukan trial and error nilai parameter rate proses biokimia di lembar kerja Global Parameters Rate atau di lembar kerja Reach Rates. Perbedaan antara lembar kerja Global Parameters Rate dengan Reach Rates adalah pada Global Parameters Rate nilai koefisien digunakan untuk keseluruhan segmen. Sedangkan pada lembar kerja Reach Rates nilai koefisien setiap segmen dapat diisi secara berbeda. Karakteristik sungai yang bervariasi dalam morfologi, hidrolika dan vegetasi memerlukan paramater-parameter yang bervariasi juga sehingga mempersulit struktur model sederhana (Marsili-Libelli et al, 2007). Nilai koefisien parameter biokimia yang digunakan dalam model kualitas air sungai Metro seperti pada Tabel 4. Dari Gambar 2 hasil kalibrasi diatas terlihat bahwa model kualitasi air COD sungai Metro mendekati data di lapangan. Untuk menilai secara kuantitatif kesesuaian model dengan kondisi nyata, selanjutnya dilakukan verifikasi model. 


\section{Verifikasi Model}

Verifikasi model dengan menggunakan Uji Chi Kuadrat dengan hasil yang didapatkan adalah nilai $\mathrm{X}^{2}$ hitung sebesar 1,09 dengan jumlah sampel adalah 6. Dari Tabel $\mathrm{X}^{2}$ untuk $\mathrm{n}=6$ dan $\alpha=0,95$, maka nilai $X^{2}$ Tabel adalah 1,145 . Sehingga model memenuhi $x^{2}$ hitung $<x^{2}$ Tabel, yaitu $1,09<1,145$. Kesimpulannya adalah model hasil kalibrasi dapat digunakan untuk simulasi.

\section{Hasil Simulasi dan Perhitungan Daya Tampung Beban Pencemaran Sungai}

Perhitungan daya tampung pencemaran sungai terhadap parameter kualitas COD berdasarkan hasil simulasi kondisi eksisting dan skenario 1 sampai 4 seperti disajikan pada Gambar 3. Sedangkan hasil perhitungan daya tampung dapat dilihat pada Tabel 5.

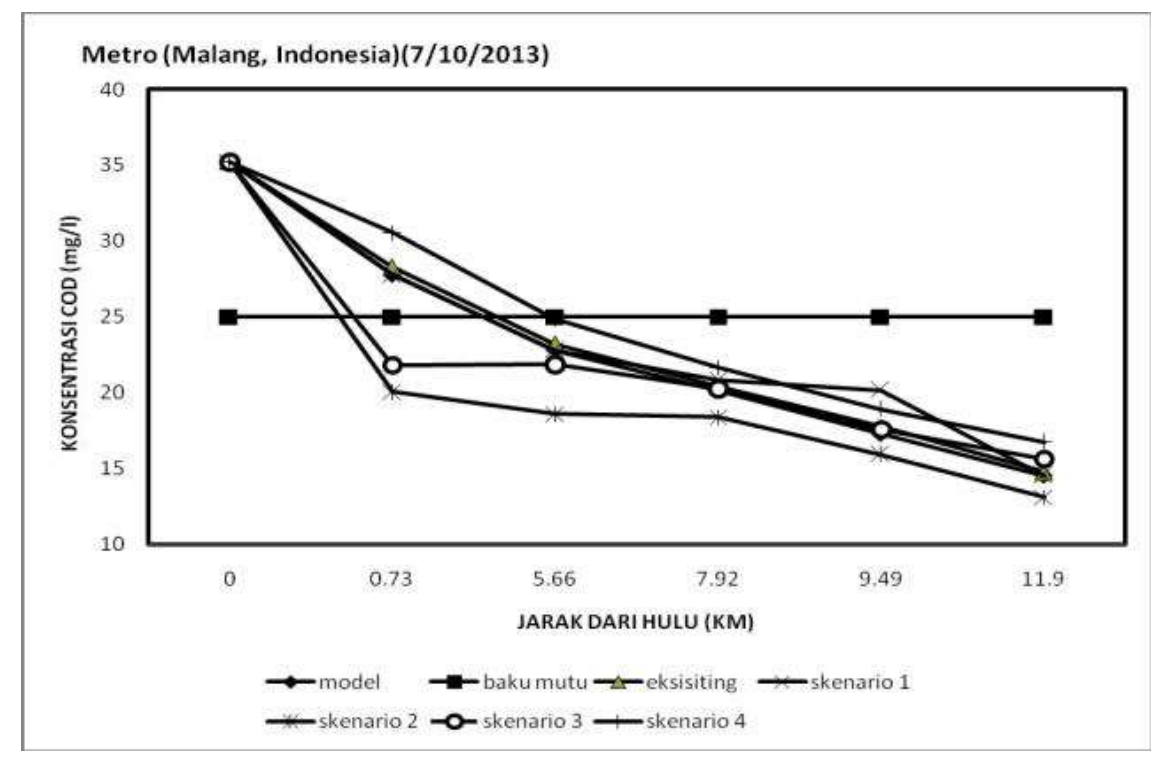

Gambar 3. Hasil Simulasi Kondisi Eksisting dan Skenario 1 sampai 4

Tabel 5. Daya Tampung Beban Pencemar

\begin{tabular}{lrrrrr}
\hline \multirow{2}{*}{$\begin{array}{l}\text { Reach } \\
\text { Label }\end{array}$} & \multicolumn{5}{c}{ Daya Tampung COD (kg/hari) } \\
\cline { 2 - 6 } & Eksisting & Skenario 1 & Skenario 2 & Skenario 3 & $\begin{array}{c}\text { Skenario } \\
\mathbf{4}\end{array}$ \\
\hline $\begin{array}{l}\text { Tlogomas } \\
\text { Karang }\end{array}$ & $-216,034$ & $-180,144$ & 321,408 & 204,768 & $-359,640$ \\
Besuki & 126,817 & 106,272 & 454,136 & 276,410 & 10,160 \\
$\begin{array}{l}\text { Pisang } \\
\text { Candi }\end{array}$ & 733,665 & 671,328 & $1.002,456$ & 742,824 & 545,408 \\
Bandulan & $1.155,643$ & 927,072 & $1.375,920$ & $1.158,805$ & 996,105 \\
Bandung & & & & & \\
Rejosari & $1.647,216$ & $1.676,721$ & $1.797,768$ & $1.489,605$ & $1.371,894$ \\
\hline
\end{tabular}




\section{- Skenario Eksisting}

Skenario ini menggambarkan keadaan dimana kualitas air di hulu Sungai Metro Kota Malang dalam keadaan eksisting,

data kualitas air sungai juga masih dalam keadaan eksisting, dan data tentang sumber pencemar juga dalam keadaan eksisting. Hasil simulasi skenario eksisting seperti pada Gambar 3.

Dari Tabel 5 terlihat bahwa sungai Metro hanya di bagian hulu yaitu reach Tlogomas saja yang memiliki daya tampung negatif, sedangkan reach-reach di bagian hilir memiliki daya tampung yang positif. Hal ini menunjukkan bahwa sungai Metro masih memiliki kemampuan menerima beban polutan COD.

\section{Skenario 1}

Skenario ini menggambarkan keadaan dimana kualitas air di hulu Sungai Metro Kota Malang dalam keadaan eksisting, data kualitas air sungai juga masih dalam keadaan eksisting, dan sumber pencemar telah memenuhi baku mutu air limbah. Output hasil simulasi skenario 1 dapat dilihat pada Gambar 3.

Pada skenario 1 dimana sumber pencemar telah memenuhi baku mutu air limbah, kualitas air parameter COD mengalami perubahan positif dan negatif di sepanjang sistem reach seperti terlihat pada Gambar 3.

\section{- Skenario 2}

Skenario ini menggambarkan keadaan dimana kualitas air di hulu Sungai Metro Kota Malang telah memenuhi baku mutu air kelas II, data kualitas air sungai dalam keadaan eksisting, dan sumber pencemar telah memenuhi baku mutu air limbah. Output hasil simulasi skenario 2 dapat dilihat pada Gambar 3.
Pada skenario 2 dimana sumber pencemar telah memenuhi baku mutu air limbah dan kondisi hulu telah memenuhi baku mutu air kelas II (sebelumnya kondisi hulu masih berada dalam kelas III). Setelah dilakukan simulasi untuk skenario 2, didapatkan nilai konsentrasi COD di bawah baku mutu. Hasil perhitungan daya tampung beban pencemar menunjukkan sungai Metro memiliki kemampuan menerima beban pencemaran seperti terlihat pada Tabel 5.

\section{- Skenario 3}

Skenario ini menggambarkan keadaan dimana kualitas air di hulu Sungai Metro Kota Malang telah memenuhi baku mutu air kelas II, data kualitas air sungai telah memenuhi baku mutu air kelas II hasil simulasi pada skenario 2, dan sumber pencemar merupakan estimasi lima tahun ke depan yaitu tahun 2018. Output hasil simulasi skenario 3 dapat dilihat pada grafik 2 . Pada skenario 3 dimana kondisi hulu telah memenuhi baku mutu air kelas II, data sungai sesuai data hasil simulasi pada skenario 2, dan data sumber pencemar merupakan estimasi lima tahun ke depan. Estimasi ini dilakukan dengan memproyeksikan jumlah penduduk di wilayah yang dilewati Sungai Metro selama lima tahun mendatang. Proyeksi jumlah penduduk ini juga untuk mendapatkan nilai debit sumber pencemar pada tahun 2018. Tujuan dari skenario ini adalah untuk mengetahui pengaruh pertambahan penduduk di wilayah Sungai Metro selama lima tahun mendatang terhadap kondisi dan daya tampung beban pencemaran sungai. Hasil simulasi skenario 3 pada Gambar 3 menunjukkan kualitas COD yang semakin tinggi (mendekati baku mutu). Sehingga daya tampung beban pencemaran Sungai Metro mengalami penurunan dibandingkan dengan kondisi sungai dengan skenario 2 seperti ditunjukan pada Tabel 5.

\section{Skenario 4}

Skenario ini menggambarkan keadaan dimana kualitas air di hulu Sungai Metro Kota Malang dalam kondisi sebenarnya, data kualitas air 
sungai dalam keadaan eksisting, dan sumber pencemar merupakan estimasi lima tahun mendatang yaitu tahun 2018 dengan konsentrasi pencemar diasumsikan dalam kondisi sebenarnya. Output hasil simulasi skenario 4 dapat dilihat pada Gambar 3.

Setelah mengetahui besar daya tampung beban pencemaran Sungai Metro pada lima tahun mendatang dengan kondisi Sungai Metro telah memenuhi baku mutu air kelas II, maka untuk selanjutnya dilakukan simulasi lima tahun mendatang dengan kondisi Sungai Metro dalam keadaan eksisting. Tujuan dari simulasi dengan skenario 4 ini adalah untuk mengetahui berapa besar daya tampung beban pencemaran Sungai Metro pada lima tahun mendatang dengan asumsi bahwa tidak ada pengelolaan kualitias air sungai selama lima tahun mendatang.

Hasil simulasi dengan skenario ini menunjukkan nilai konsentrasi COD di atas baku mutu pada daerah hulu (segmen 1 dan 2). Pada kondisi ini, Sungai Metro masih memiliki daya tampung beban pencemar COD kecuali di segmen 1 seperti ditunjukan pada Tabel 5.

Hal-hal yang harus dilakukan untuk dapat melakukan peningkatan kualitas sungai adalah dengan melakukan pengelolaan kualitas air sungai. Pengelolaan kualitas air ini berdasarkan pasal 4 Peraturan Pemerintah Nomor 82 Tahun 2001 tentang Pengelolaan Kualitas Air dan Pengendalian Pencemaran Air bertujuan untuk menjamin kualitas air yang diinginkan sesuai dengan peruntukannya agar tetap dalam kondisi alamiahnya. Selain pengendalian air limbah yang masuk ke dalam sungai, pengelolaan air Sungai Metro dapat dilakukan pengelolaan sampah secara terpadu. Kondisi eksisting Sungai Metro saat ini adalah banyak sampah yang dibuang penduduk sekitar daerah aliran sungai. Sampah-sampah yang dibuang ke sungai ini terutama sampah yang bersifat organik sangat mempengaruhi jumlah oksigen terlarut di dalam sungai. Oksigen terlarut ini akan digunakan bakteri untuk mendegradasikan sampah organik ini sehingga berpengaruh pula terhadap kebutuhan oksigen di dalam air. Selain pengelolaan sampah secara terpadu, pengelolaan kualitas air Sungai Metro juga dapat dilakukan dengan pemantauan kualitas air secara berkala. Pemantauan kualitas air Sungai Metro secara berkala, akan segera memberi data tentang kualitas air sehingga dapat cepat dilakukan tindakan pemulihan kualitas air.

Penetapan kelas air juga penting untuk dilakukan mengingat sampai saat ini masih belum adanya sebuah penetapan kelas air secara spesifik untuk Sungai Metro. Penetapan kelas air sangat penting untuk dapat mengetahui batas kandungan konsentrasi pencemar yang sesuai dengan peruntukannya. Pengelolaan kualitas air sungai juga dapat dilakukan dengan penataan kembali daerah permukiman di wilayah sempadan Sungai Metro. Daerah permukiman warga di wilayah Kota Malang dimana dalam kegiatannya menghasilkan limbah domestik, diketahui mempunyai kontribusi sumber pencemar yang cukup signifikan mengingat limbah domestik yang dihasilkan langsung dibuang menuju sungai. Oleh sebab itu, penataan daerah permukiman warga di sempadan Sungai Metro dapat diimplementasikan dengan pembuatan Instalasi Pengolahan Air Limbah sehingga limbah domestik yang dibuang ke sungai telah memenuhi baku mutu air limbah.

Penataan kembali daerah permukiman dengan membangun IPAL si wilayah sempadan Sungai Metro bertujuan untuk meminimalisir kegiatan pembuangan limbah domestik tercemar ke sungai. Kegiatan pengelolaan kualitas air dapat meningkatkan kesehatan masyarakat dan ekosistem (Orouji, et al., 2013). Dengan kegiatan pengelolaan kualitas air secara terpadu yang meliputi penurunan konsentrasi pencemar di hulu, penurunan konsentrasi pencemar pada sumber pencemar, penetapan kelas air, dan juga pengelolaan sampah, maka kualitas air Sungai Metro akan semakin meningkat dan mempengaruhi besarnya daya tampung beban pencemaran yang dimiliki oleh Sungai Metro. 


\section{Penurunan Beban Pencemar Sungai}

Penurunan beban pencemar sungai berfungsi untuk mengetahui berapa persentase kandungan pencemar yang harus diturunkan sehingga Sungai Metro menjadi sungai yang memenuhi baku mutu air kelas II.
Perhitungan penurunan beban pencemar ini dapat menggunakan persamaan sebagai berikut :

$$
\text { Penurunan Beban Pencemar (\%) = }
$$

Beban Pencemaran Skenario Kondisi sebenarnya - Beban Pencemaran Skenario 2

Beban Pencemaran Skenario Eksisting

Penurunan beban pencemar Sungai Metro secara keseluruhan untuk masing-masing segmen dan masing-masing parameter dapat dilihat pada Tabel 6 .

Tabel 6. Persentase Penurunan Beban Pencemaran

\begin{tabular}{lc}
\hline \multicolumn{1}{c}{$\begin{array}{c}\text { Reach } \\
\text { Label }\end{array}$} & $\begin{array}{c}\text { Generic C. } \\
\text { (COD) } \\
\text { \% }\end{array}$ \\
\hline Tlogomas & 30.09 \\
Karang Besuki & 19.90 \\
Pisang Candi & 14.86 \\
Bandulan & 15.36 \\
Bandung Rejosari & 14.93 \\
\hline
\end{tabular}

\section{KESIMPULAN}

Nilai daya tampung beban pencemaran sungai yang baik untuk lima tahun mendatang dapat dicapai dengan pengelolaan kualitas air skenario 2.

Pada skenario 2, kondisi hulu sesuai dengan baku mutu sungai kelas II dan kuantitas beban pencemaran pada kondisi eksisting, kualitasnya sesuai dengan baku mutu air limbah. Segmen 1 sungai Metro memiliki beban pencemaran yang paling tinggi sehingga untuk mencapai kondisi terbaik seperti pada skenario 2 harus dilakukan penurunan beban pencemaran COD sebesar $30,09 \%$.

\section{DAFTAR PUSTAKA}

Alaerts, G. dan Santika, S.S. 1987. Metode Penelitian Air. Penerbit Usaha Nasional. Surabaya.

Baidowi, Ahmad. 2010. Pemodelan Kualitas Air Sungai Menggunakan Qual 2K: Studi Kasus Sungai Secang Kabupaten Kulon Progo Provinsi Daerah Istimewa Yogyakarta. Program Studi S2 Kimia. UGM Yogyakarta.

Brantas, B. 2006. Pola Pengelolaan SDA WS Brantas.

Chapra, S.C. and Pelletier, G.J. 2003. QUAL2K: A Modeling Framework for Simulating River and Stream Water Quality: Documentation and Users Manual. Civil and Environmental Engineering Dept., Tufts University, Medford, MA.

Fadly, N. Aliefia. 2008. Daya Tampung dan Daya Dukung Sungai Ciliwung Serta Strategi Pengelolaannya. Program Studi Teknik Sipil. Universitas Indonesia. Jakarta.

Hendriarianti, E. 2012. Hydrogeometry And Water Quality Data Analysis For One Dimension Water Quality Modelling Of Lesti River At Malang Regency. J. Appl. Environ. Biol. Sci., 2(6)232-243. 
(http://kali-brantas-kota

malang.weebly.com/berita.html, 2012)

Keputusan Menteri Lingkungan Hidup Nomor 110 Tahun 2003. Pedoman Penetapan Daya Tampung beban Pencemaran Air Pada Sumber Air.

Marsili-Libelli, S*; Giusti Elisabetta. Water quality modelling for small river basin. Environmental Modelling \& Software 23., halaman 451- 463.

Nugraha, W. Dwi. 2008. Identifikasi Kelas Air dan Penentuan Daya Tampung Beban Cemaran BOD Sungai dengan Model Qual 2E (Studi Kasus Sungai
Serayu Jawa Tengah). Jurnal Presipitasi. Universitas Diponegoro. Semarang.

Orouji, H., Bozorg Haddad, O., FallahMehdipour, E., and Mariño, M. 2013. Modeling of Water Quality Parameters Using Data-Driven Models. J. Environ. Eng., 139(7), 947-957.

Peraturan Pemerintah Republik Indonesia Nomor 38 Tahun 2003. Sungai.

Peraturan Pemerintah Republik Indonesia Nomor 82 Tahun 2001. Pengelolaan Kualitas Air dan Pengendalian Pencemaran Air. 